\title{
Sugarcane Production in Nepal
}

\section{Swodesh Rijal*}

Faculty of Agriculture, Agriculture and Forestry University, Rampur, Chitwan, Nepal

*Corresponding Author: Swodesh Rijal, Faculty of Agriculture, Agriculture and Forestry University, Rampur, Chitwan, Nepal.

Received: June 11, 2019; Published: July 08, 2019

DOI: $10.31080 /$ ASAG.2019.03.0567

\section{Introduction}

Sugarcane is tall perennial true grasses of family Saccharum. The word "Saccharam" derived from Sanskrit word 'sarkara' which means sugar. Sugarcane is the main source of producing sugar in Nepal. Sugarcane was originally native of Asia but later spread quickly throughout the world. All current commercial sugarcanes are result of cross breeding of original native. Sugarcane is the world largest crop. The largest producer of sugarcane is Brazil, India, China, Pakistan, Thailand and Mexico. Of the world's total production of sugar sugarcane contributed around $60 \%$. Nepal ranked in 41st position in sugarcane production.

\section{Sugarcane production}

Sugarcane is a tropical plant with long growing season (270360 days), widely distributed in subtropics too.

\section{Environment}

Soil

Optimum soil environment is basic requirement for achieving higher yields. Sugarcane can be grown in all types of soil but well drained loam soil is best. Since Sugarcane is a gross feeder crop, the soil should be of high natural fertility. Ideally water availability and oxygen supply should be $15 \mathrm{~cm} / \mathrm{m}$ and 3.4 respectively. It can be grown in considerable degree of soil acidity and alkalinity but optimum $\mathrm{pH}$ is about 6.5. Among the soil parameters, bulk density seems important and critical value is $1.8-1.9 \mathrm{~g} / \mathrm{cm}^{3}$.

\section{Temperature}

Soil Temperature

\begin{tabular}{|l|c|}
\hline \multicolumn{1}{|c|}{ Description } & Optimum temperature required $\left({ }^{\circ} \mathbf{C}\right)$ \\
\hline Sprouting & $27-38$ \\
\hline Root formation & $>12$ \\
\hline
\end{tabular}

Table 1
Soil Temperature

\begin{tabular}{|l|l|}
\hline Description & Optimum Temperature $\left({ }^{\circ} \mathbf{C}\right)$ \\
\hline Cane growth & $24-30$ \\
\hline Tillering & 30 \\
\hline Elonagtion & 31 @day, 20@ night \\
\hline Ripening & 24 \\
\hline Sugar quality & \\
\hline Sugar synthesis & 30 \\
\hline
\end{tabular}

Table 2

\section{Moisture}

For obtaining better yield $2000-2500 \mathrm{~mm} /$ annum of rainfall is required.

\begin{tabular}{|l|c|c|}
\hline Growth stages & $\begin{array}{c}\text { Rainfall } \\
\text { (mm) }\end{array}$ & $\begin{array}{c}\text { Duration (Days } \\
\text { after planting) }\end{array}$ \\
\hline Germinative & 300 & $0-45$ \\
\hline Tillering & 550 & $45-120$ \\
\hline Grand growth & 1000 & $120-270$ \\
\hline Maturity & 650 & $270-360$ \\
\hline Total & 2500 & \\
\hline
\end{tabular}

Table 3

Light

Light is important factor influencing growth, tillering and cane development. Sugarcane is sun loving plant. About 7-10 hours of bright sunlight is highly useful for active growth and ripening.

Some cultivated varieties of sugarcane in Nepal

\begin{tabular}{|l|c|c|}
\hline Varieties & Maturity days & Productivity(mt/ha) \\
\hline Jitpur 1 & $300-360$ & 71 \\
\hline Jitpur 2 & $300-360$ & 92 \\
\hline Jitpur 3 & $300-360$ & 79.2 \\
\hline Jitpur 4 & $300-360$ & 86 \\
\hline
\end{tabular}

Table 4 


\section{Seeds and Sowing}

Sugarcane is propagated vegetatively by stem cutting of immature canes known as sets. Top $1 / 3$ to $1 / 2$ portion of cane being immature having high glucose content good for germination.

Three budded : 35,000-45,000 setts/ha.

Setts should be treated with $0.5 \%$ solution of Agallol or Aretan.

Time of planting

- Spring planting: Magh-Falgun (Jan-Feb)

- Autumn Planting: Ashoj-Karthik (Sep-Oct)

Planting methods

- $\quad$ Flat planting

- Flat planting is followed in subtropical areas of Nepal.

- $\quad$ Planted shallow 8-10 cm deep furrows at 75-90 cm distance.

- After planting setts are covered with 5-7 cm layers of soil followed by leveling with planking.

- Furrow planting method

- Furrows of $15-20 \mathrm{~cm}$ depth are made with local plough or spade at a distance of $90 \mathrm{~cm}$ apart from each other.

- Followed particularly in heavy soil.

- $\quad$ Trench method

- Suitable for tall growing cane areas to protect from lodging.

Manures and fertilizer

- Heavy feeder crop but higher doses of Nitrogen during ripening stage decrease sucrose content in maturing canes.

- General recommendation dose: 90-130:45-100: 100-200 $\mathrm{kg} \mathrm{NPK/ha}$

- In Nepal, Blanket application of Nitrogen (120): Phosphorus (60): Potash (40) in kg/ha.

- The best source of nitrogen in normal soil is Ammonium sulphate, urea in saline and CAN in acidic soil.

\section{Irrigation}

- $\quad$ Sugarcane being a long duration crop requires larger quantity of water.

- 200 tons of water is used in producing 1 ton of sugarcane.

- Furrow method of irrigation is most common method.
Plant Management practices

- Hoeing

- After 10-15 days of planting hoeing should be conducted

- 1-2 hoeing are done according to need.

- Blind hoeing is an important practice in sugarcane, hoeing after planting and before crop emergences for the purpose of weed control.

- $\quad$ Gap filling

- $\quad$ After 20-30 days of planting, the place without sprouts be filled with new setts.

- Weed management

- Heavy weed growth during initiation phase which cause yield loss upto $60 \%$.

- Used of chemical i.e.

- Pre-emergence application of Atrazine $1 \mathrm{~kg}$ a.i./ha (0-3DAP) mixed in 60 liters of water.

- Post emergence directed application of glyphosate@1.0 litre on 45 DAPS.

- $\quad$ Earthing up

- $\quad$ Earthing up operation is done 2-3 times. It is done either manually or a tractor drawn ridger.

- Detrashing

- It is removal of dry and lower green leaves.

- Detrashing is done manually

- Wrapping and propping

- Bending down of number of leaves of the cane and wrapped it.

- During wrapping two or more cane clumps are tied together for additional strength and to prevent their lodging.

- Strong bamboos are also used as props to prevent lodging.

\section{Harvesting}

Cane maturity can be measured by

1. Brix value: Sugarcane consider mature if brix value is 1618 (refractometer reading).

2. Fehling test: for maturation of cane Fehling test solution reading should be less than $0.5 \%$ glucose.

Harvesting of cane is done any time except extreme hot or cold months. 
Falgun- Chaitra (March -April) is best time for harvesting.

- Harvesting of plant is done close to the ground for more yield and for better ratoon crop.

Economic importance

By products of Sugarcane

- Molasses

- It is the dark brown viscous liquid which contains about $35 \%$ sucrose and $15 \%$ reducing sugars.

- Used for alcohol production.

- $\quad$ Rum is the best potable spirit made from it and food yeast also prepared from it.

- Valuable additive in the preparation of silage.

- $\quad$ Bagasses

- $\quad$ Main source of fuel in sugar factories.

- It is used in the manufacture of paper, cardboard, plastics and wallboard.

- Due to of its chemical composition and potential availability bagasses is well suited to manufacture of plastics.

- $\quad$ Press mud

- It is the source of cane wax.

- contain lime, reclamation of acidic soils.

In Brazil, sugar cane is used as a source of energy. Gasohol (80\% petrol $+20 \%$ alcohol) is prepared from sugarcane which is used in automobiles. Sugarcane provides the cheapest form of energy giving food with lowest unit of land per unit of energy produced. In Nepal more than 100,000 farm families depend upon it. So, it plays vital role in poverty alleviation in rural areas.

\section{Challenges for production}

Nepal has huge opportunities in sugarcane farming. However, gap between pricing and payment, bitter relationship between farmers and sugar producers, lack of improved variety, trade issues and mechanization are the issues that limited the commercialization of sugarcane farming. Sugarcane farmers in Nepal never get a proper price for their produce. So, Government of Nepal must fix a minimum price for sugarcane. For the solution of problem government of Nepal should establish sugarcane board for development of this field.

\section{Volume 3 Issue 8 August 2019}

(C) All rights are reserved by Swodesh Rijal. 